\title{
The distribution of breeding birds in the KüçüK Menderes Delta in WESTERN TURKEY
}

\section{Razširjenost gnezdilk v delti Küçük Menderes (zahodna Turčija)}

\author{
Fethi Bengil ${ }^{1}$, Bariş Uzilday ${ }^{2}$ \& Mehmet Siki ${ }^{2}$ \\ ${ }^{1}$ Institute of Marine Sciences and Technology, Dokuz Eylül University, Haydar Aliyev Bulv. No. 100, TR-35340 \\ İnciraltı, İzmir, Turkey, e-mail: fethi.bengil@ogr.deu.edu.tr \\ ${ }^{2}$ Department of Biology, Faculty of Science, Ege University, TR-35100 Bomova, İzmir, Turkey
}

\begin{abstract}
Between 3 and 18 May, 2008, the status and distribution of breeding birds in Küçük Menderes Delta on the coast of the Aegean Sea in western Turkey was investigated. The $49 \mathrm{~km}^{2}$ large study area was divided into $491 \times 1 \mathrm{~km}$ UTM squares. In all squares, $2-3$ point counts, i.e. a total of 139 counts, were conducted. From a total of 54 bird species for which breeding evidence was obtained, 19 species (35\%) were classified as possible breeding and $23(43 \%)$ as probably breeding birds, while for 12 species (22\%) breeding was confirmed. The current distribution of all breeding species is presented in maps. Crested Lark Galerida cristata, Cetti's Warbler Cettia cetti, House Sparrow Passer domesticus and Olivaceous Warbler Hippolais pallida were found in $>50 \%$ of all squares. More than 10 breeding species were found in squares containing different aquatic and seasonally flooded habitats along the shore-line of the Aegean Sea and in the surroundings of brackish and freshwater lakes, while in many squares, which contain large portions of agriculturally used land and salt mud-flats, less than 10 breeding species were recorded. Low numbers of breeding waterbirds in the Delta are attributed to the burning of reedbeds during the nesting season and human disturbances, like recreation activities and illegal bird shooting.
\end{abstract}

Key Words: Küçük Menderes Delta, Western Turkey, breeding bird atlas, avifauna, distribution, breeding bird diversity

Ključne besede: delta Küçük Menderes, zahodna Turčija, atlas gnezdilk, avifavna, razširjenost, pestrost gnezdilk

\section{Introduction}

According to its high species diversity, extensive food chains and significance for water resources, pristine wetland habitats, untouched by humans, constitute some of the planet's most precious ecosystems. By considering its extraordinary biodiversity, MiтsCH \& Gosselink (2007) have called them "ecological supermarkets", which are protected under international conventions, national laws and local regulations for water and habitat management. The numerous wetlands in the Turkish Mediterranean region, like marshlands, lakes, rivers, floodplains, estuaries and other natural and anthropogenic wetland habitats, harbour significant components of the country's biodiversity (KARADENIZ et al. 2009).

Besides other coastal wetlands in Turkey, which meet BirdLife International's criteria for the designation of Important Bird Areas (IBAs), the numbers of two bird species surpass the threshold of the IBA criteria in the Küçük Menderes River: Pygmy Cormorant Phalacrocorax pygmaeus (wintering population 35-160 birds) and Spur-winged Plover Vanellusspinosus (10-13 breeding pairs) (KILIÇ \& EKEN 2004). According to EKEN et al. (2006), the Delta further fulfills the criteria as a Key Biodiversity Area (KBA) for both species, criterion 2 of the Ramsar Convention (BirdLife INTERNATIONAL 20OI) and, additionally, harbours a 


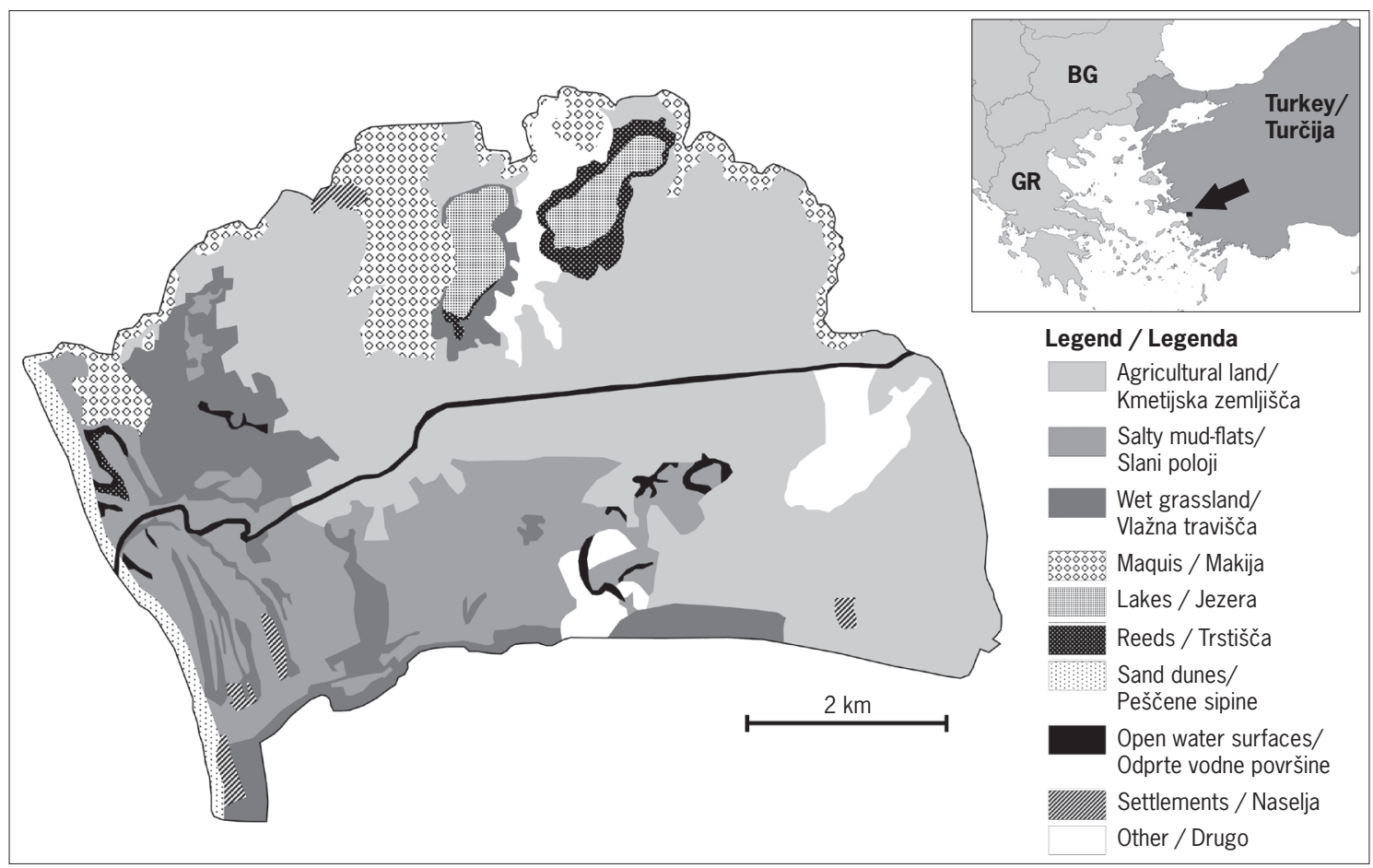

Figure 1: Map of the study area in the Küçük Menderes Delta in western Turkey showing main habitat types

Slika 1: Zemljevid raziskovanega območja v delti Küçük Menderes (zahodna Turčija) z glavnimi tipi habitatov

small wintering population of globally threatened Dalmatian Pelicans Pelecanus crispus (AKARsu \& BALKIZ 20IO). Although the Government of Turkey has recently designated the Küçük Menderes Delta a Wildlife Development Area (SIT) and in spite of the fact that the area has been legally protected since 1991, the Delta's wetland habitats and its wildlife keep deteriorating (EKEN et al. 2006).

Previous ornithological studies have been largely restricted to a few locations or to some aspects of the Delta's birdlife (SusEven et al. 2006, Onmuş 2007, KusBank 20IO). In particular, SiKi (1997) has reported qualitative information on the bird fauna of the Akgöl and Barutcu region in the Küçük Menderes Delta, but has not included the data on spatial distribution. Therefore, the main goal of the present study has been to investigate the current distribution and relative abundances of the breeding birds within the protection areas in the Küçük Menderes Delta and its surroundings. By applying currently widely used atlas techniques in different parts of the world (e.g. EagLes I990, Gregory et al. 1996, Donald \& Fuller 1998) and Turkey (Per et al. 2002, Onmuş et al. 2009), we wish to stimulate science based conservation planning and help with the development of adequate management strategies in the area. We further intended to provide baseline information for the comparison of current and future distribution patterns and the relative abundances of breeding birds in the Delta.

\section{Study area and methods}

\subsection{Study area}

The study area is situated in the Küçük Menderes River Delta in the district of Selçuk (province İzmir), on the Aegean coast in western Turkey (Figure 1). 4,440 ha of the Delta's alluvial lowlands have been designated as IBA TR018 Küçük Menderes Delta by BirdLife International and 1,500 and 1,000 ha of that area is covered by Permanent Wildlife Reserve and Wildlife Development Area (SIT), respectively (Heath \& Evans 2000, BirdLife InTERnATIONAL 2OII). With a long-term average temperature of $16.7^{\circ} \mathrm{C}$ and a total annual rainfall of $570 \mathrm{~mm}$, the Delta is characterized by a Mediterranean climate (SOMAY et al. 2008).

Our 4,296 ha large study area corresponds well to the designated IBA along the Küçük Menderes 
Table 1: Surface areas and land coverage of main habitat types in the study area in the Küçük Menderes Delta

Tabela 1: Površine in pokritost glavnih tipov habitatov v raziskovanem območju delte Küçük Menderes

\begin{tabular}{lcc}
\hline Main habitat type / Glavni tip habitata & $\begin{array}{c}\text { Surface area/ } \\
\text { Površina }\left(\mathrm{km}^{2}\right)\end{array}$ & $\begin{array}{c}\text { Land coverage/ } \\
\text { Pokritost (\%) }\end{array}$ \\
\hline Agricultural land / Kmetijska zemljišča & $\mathrm{I} 9.9$ & 46.3 \\
Salty mud-flats / Slani poloji & 8.4 & 19.5 \\
Wet grassland / Vlažna travišča & 4.9 & $\mathrm{II} .4$ \\
Maquis / Makija & 3.6 & 8.4 \\
Lakes / Jezera & $\mathrm{I} . \mathrm{I}$ & 2.6 \\
Reeds / Trstišča & 0.8 & $\mathrm{I} .9$ \\
Sand dunes / Pě̌čene sipine & 0.5 & $\mathrm{I} .2$ \\
Open water surfaces / Odprte vodne površine & 0.3 & 0.7 \\
Settlements / Naselja & 0.3 & 0.7 \\
Other / Drugo & 3.2 & 7.4 \\
\hline Total / Skupaj & \multicolumn{2}{c}{0.0} \\
\hline
\end{tabular}

River. The most characteristic habitat types of the area include agricultural lands, salty mud-flats, maquis, wet grasslands, sand dunes, reedbeds, open water surface of the river and its tributaries, lagoons, brackish and freshwater lakes as well as human settlements (Table 1). The prevailing plant species of the seasonally flooded salt mud-flats are tamarisk Tamarix sp. and Common Glasswort Salicornia europaea, while along the shores of inland lakes and lagoons bulrush Typha sp. and on sand dunes along the coast-line Sea Daffodil Pancratium maritimum, a Mediterranean endemic, are growing. A map, which shows the main habitat types of the study area, is given in Figure 1.

During the last 80 years, large areas of the alluvial lowlands have been transformed into agricultural lands (BolCA et al. 2005). Recently, mainly cotton and different fruits, like peach, apricot and cherry, have been grown in the Delta. Most of the surrounding higher ground is covered with olive groves.

\subsection{Methods}

For collecting and later presentation of bird data, the study area has been divided into $491 \times 1 \mathrm{~km}$ wide squares (UTM grid). Field work was conducted between 3 and 18 May 2008. Up to three standardized point counts (duration $10 \mathrm{~min}$ ) were conducted per UTM square. With a minimum distance of $250 \mathrm{~m}$ between survey points as far as possible within squares survey points were located along the boundaries between main habitat types (BiввY et al. 1998). For all point counts, UTM coordinates, time of day, habitat type(s), human disturbances and all birds that were seen or heard were noted separately. In all 139 point counts, i.e. a mean of 2.8 counts per UTM square, were performed throughout the study area. Point counting was conducted during day time hours between early morning and dusk with survey belts standardized to $100 \mathrm{~m}$ around points. In addition to the data of point counts, observations outside $100 \mathrm{~m}$ survey belts and other occasional observations of birds were recorded on separate record sheets. Standard EBCC breeding codes were used for classifying the breeding status (Hagemeijer \& Blair I997) and together with all field data stored in a computer database.

On the basis of this database, distribution maps for all bird species with breeding evidence have been prepared. The highest breeding code per species and $1 \times 1 \mathrm{~km}$ UTM square - possible, probably or confirmed breeding categories - was assigned as the overall breeding evidence for the given square and used for the preparation of the distribution maps. For calculating the total number of species and species diversity, the Geographical Information System (GIS) was used by superposing the GIS-layers for all bird species recorded per UTM square.

\section{Results and discussion}

During the study period in May 2008, breeding evidence for a total of 54 bird species was gathered in the Küçük Menderes Delta (Table 2, Appendix 1). Of these, 19 species (35\%) were classified as possible breeding and 23 (43\%) as probably breeding birds, while for 12 species (22\%) breeding was actually confirmed. 
Table 2: List of bird species with breeding evidence and distribution frequencies in the study area in the Küçük Menderes Delta in 2008 (breeding categories: A - possible breeding, B - probable breeding, C - confirmed breeding; the highest breeding category established for individual species is given as a breeding status.). Distribution frequencies are indicated by the number (N) and percentage (\%) of squares in which the respective species was recorded.

Tabela 2: Seznam ptičjih vrst z gnezditvenim statusom in frekvencami razširjenosti leta 2008 v raziskovanem območju delte Küçük Menderes (kategorije gnezdenja: A - možno gnezdenje, B - verjetno gnezdenje, C - potrjeno gnezdenje; najvišja kategorija gnezdenja, ugotovljena za posamezno vrsto, je podana kot gnezditveni status). Frekvence razširjenosti so označene s številom (N) in odstotkom (\%) kvadratov, v katerih so bile zabeležene posamezne vrste.

\begin{tabular}{|c|c|c|c|}
\hline \multirow{2}{*}{ Species / Vrsta } & \multirow{2}{*}{$\begin{array}{l}\text { Breeding status/ } \\
\text { Gnezditveni status }\end{array}$} & \multicolumn{2}{|c|}{ Distribution frequency / Frekvenca razširjenost } \\
\hline & & $\mathrm{N}$ & $\%$ \\
\hline Galerida cristata & $\mathrm{C}$ & 32 & 65.3 \\
\hline Cettia cetti & $\mathrm{B}$ & $3 \mathrm{I}$ & 63.3 \\
\hline Passer domesticus & $\mathrm{C}$ & 30 & 61.2 \\
\hline Hippolais pallida & A & 26 & 53.1 \\
\hline Pica pica & $\mathrm{B}$ & 23 & 46.9 \\
\hline Remiz pendulinus & $\mathrm{C}$ & I7 & 34.7 \\
\hline Miliaria calandra & A & I6 & 32.7 \\
\hline Carduelis carduelis & $\mathrm{B}$ & I6 & 32.7 \\
\hline Acrocephalus scirpaceus & $\mathrm{B}$ & I4 & 28.6 \\
\hline Streptopelia decaocto & $\mathrm{B}$ & I2 & 24.5 \\
\hline Hirundo rustica & $\mathrm{C}$ & $\mathrm{I} 2$ & 24.5 \\
\hline Passer hispaniolensis & $\mathrm{C}$ & IO & 20.4 \\
\hline Turdus merula & B & IO & 20.4 \\
\hline Garrulus glandarius & A & 8 & I6.3 \\
\hline Motacilla flava & B & 8 & I6.3 \\
\hline Acrocephalus arundinaceus & A & 8 & 16.3 \\
\hline Ciconia ciconia & C & 7 & $\mathrm{I} 4 \cdot 3$ \\
\hline Parus major & B & 7 & $\mathrm{I} 4 \cdot 3$ \\
\hline Tadorna ferruginea & B & 6 & $\mathrm{I} 2.2$ \\
\hline Gallinula chloropus & A & 6 & $\mathrm{I} 2.2$ \\
\hline Emberiza melanocephala & B & 6 & $\mathrm{I} 2.2$ \\
\hline Himantopus himantopus & $\mathrm{C}$ & 5 & IO.2 \\
\hline Melanocorypha calandra & B & 5 & IO.2 \\
\hline Corvus monedula & B & 5 & IO.2 \\
\hline Lanius collurio & A & 5 & IO.2 \\
\hline Lanius senator & $\mathrm{C}$ & 5 & IO.2 \\
\hline Anas platyrhynchos & B & 4 & 8.2 \\
\hline Corvus cornix & B & 4 & 8.2 \\
\hline Streptopelia turtur & B & 3 & 6.I \\
\hline Charadrius alexandrinus & B & 2 & 4.I \\
\hline Vanellus spinosus & $\mathrm{C}$ & 2 & $4 . I$ \\
\hline Chlidonias leucopterus & B & 2 & $4 . I$ \\
\hline Emberiza cirlus & B & 2 & $4 . I$ \\
\hline Carduelis chloris & B & 2 & 4.I \\
\hline Delichon urbicum & A & 2 & $4 . \mathrm{I}$ \\
\hline Lanius minor & A & 2 & $4 . \mathrm{I}$ \\
\hline Buteo buteo & B & I & 2.0 \\
\hline Charadrius dubius & A & I & 2.0 \\
\hline Glareola pratincola & B & I & 2.0 \\
\hline Actitis hypoleucos & A & I & 2.0 \\
\hline Tringa totanus & A & I & 2.0 \\
\hline Chlidonias niger & B & I & 2.0 \\
\hline Ixobrychus minutus & A & I & 2.0 \\
\hline Coracias garrulus & $\mathrm{C}$ & I & 2.0 \\
\hline Upира ерорs & A & I & 2.0 \\
\hline Clamator glandarius & A & I & 2.0 \\
\hline Cuculus canorus & A & I & 2.0 \\
\hline Falco tinnunculus & $\mathrm{C}$ & I & 2.0 \\
\hline Fulica atra & B & I & 2.0 \\
\hline Muscicapa striata & A & I & 2.0 \\
\hline Cisticola juncidis & A & I & 2.0 \\
\hline Saxicola torquatus & $\mathrm{C}$ & I & 2.0 \\
\hline Dendrocopos syriacus & A & I & 2.0 \\
\hline Athene noctua & $\mathrm{A}$ & $\mathrm{I}$ & 2.0 \\
\hline
\end{tabular}


The total number of species per UTM square varied between one and 24 species (Figure 2). In general, in squares containing two or more habitat types more breeding birds were noted than in uniform squares, covered by only one of the main habitat types shown in Table 1. The square, which harbours the highest number of species, is located close to the shore-line of the Aegean Sea, includes outflow of the main river to the sea and encompasses sand flats, sand dunes, open water surfaces, salt marshes and pastures. Here a number of waterbirds, waders and different grassland birds were found. Some squares containing larger numbers of breeding birds ( $\geq 10$ species) are located around Gebekirse and Çakal Lakes as well as around some temporary water beds (Figure 2). Although we have found very little breeding evidence for waterbirds, the high species diversity illustrates the significance of both inland lakes for conservation.

Many squares that contain large areas of salt pastures and agricultural lands harbour lower numbers of species $(<10)$ per square (Figure 2). In squares covered by $\geq 80 \%$ of its area with agriculturally used land and salt mud-flats, total numbers of 2-20 species (mean $\pm \mathrm{SD}=9.1 \pm 4.4, \mathrm{n}=15)$ and $4-24$ breeding bird species (mean $\pm S D=10.3 \pm 8.2, \mathrm{n}=6$ ) were recorded, respectively. The rather wide range of bird species diversity in squares of both main habitat types apparently derives from the presence of landscape elements, like strips of unused land along ditches, bushes and solitary trees. In agriculturally used land, Crested Lark Galerida cristata, House Sparrow Passer domesticus and Common Magpie Pica pica are the most frequently noted species, while in squares that encompass large portions of salt pastures, Cetti's Warbler Cettia cetti and Corn Bunting Miliaria calandra were found most frequently (Appendix 1).

We measured the relative abundance of all breeding species in the study area by calculating the distribution frequency, i.e. the proportion of positive squares per species. According to the data shown in Table 2 , with a proportion of $>50 \%$ of positive squares, Crested Lark, Cetti's Warbler, House Sparrow and Olivaceous Warbler Hippolais pallida are the most widely distributed species in the area. Additionally, some passerines which are associated with riverine and marshland habitats, like Penduline Tit Remiz pendulinus and Reed Warbler Acrocephalus scirpaceus, are relatively abundant in the Delta. In contrast, most non-passerine waterbirds were found in very low frequencies $(<10 \%)$. Beside the White Stork Ciconia ciconia, which nests with at least seven breeding pairs in the Delta, Ruddy Shelduck Tadorna ferruginea, Common Moorhen Gallinula chloropus and Black-

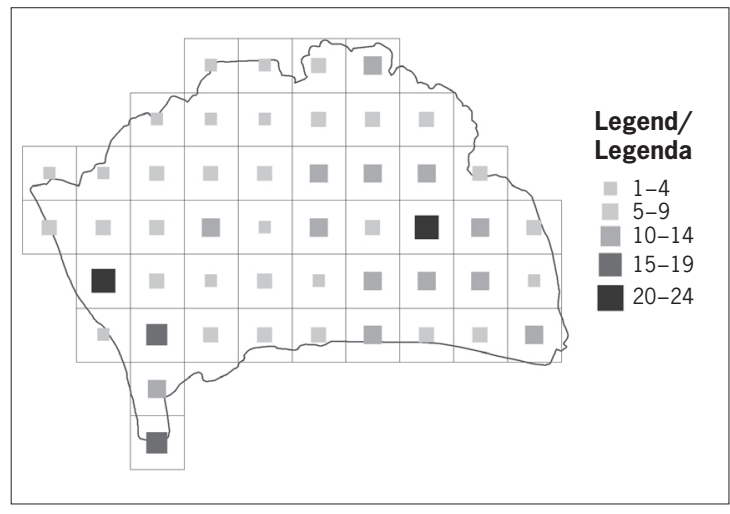

Figure 2: Total numbers of breeding birds per $1 \times 1$ $\mathrm{km}$ UTM square $(n=49)$ in the study area of the Küçük Menderes Delta in 2008

Slika 2: Skupno število gnezdečih ptic na $1 \times 1 \mathrm{~km}$ UTM-mrežo $(n=49)$ v območju delte Küçük Menderes, raziskanem leta 2008

winged Stilt Himantopus himantopus are the most widely distributed waterbirds (distribution frequencies 10-12\%).

Although KILIÇ \& EKEN (2004) give an estimate of 10-13 breeding pairs of Spur-winged Plover present there, we observed only two solitary pairs in widely separated UTM squares. Spur-winged Plover is the only breeding species for which the Küçük Menderes Delta qualifies as IBA. Moreover, the species national and European conservation status was given as Vulnerable, based on apparently decreasing population trend (Birdife International 2004, Kirwan et al. 2008) and should be treated as one of the priority species of our area. In similar study conducted by OnMUş et al. (2009) in 7 times larger Gediz Delta, the nearest another delta to our study area, located ca. $80 \mathrm{~km}$ to the north along the Aegean coast, Spur-winged Plover was found breeding in as many as $231 \times 1$ UTM squares. However, the authors mention Spur-winged Plover as one of the species mostly affected by ongoing habitat loss in that area as well.

In particular, the numbers of colonial nesting waterbirds appear to be very low in the area. Although we saw territorial and breeding displays of small groups of Black Chlidonias niger and White-winged Black Terns C. leucopterus during the bird surveys, both sites were deserted till the end of our study in late May owing to various tourist activities and the drying out of the prospective nesting sites on small islets. Similarly, we found no breeding evidence for Yellow-legged Gulls Larus michahellis, although the species was present in good numbers throughout 
the study period. We suppose that due to extensive human activities and illegal bird shooting the species is currently unable to nest in the area. According to our experiences, irregularly fluctuating water levels and extensive human disturbances through agricultural activities, tourism and hunting are the main reasons for the low number of breeding waterbirds in the Delta. In the Wildlife Development Area surrounding Lake Gebekirse as well as around Lake Akgöl, reedbeds were illegally burnt down during the study period, which is presumably the reason for the lack of any breeding evidence for waterbirds on both inland lakes. In addition, inadequately managed waste waters from residential areas and industrial facilities are main sources of pollution in the Küçük Menderes Delta. The absence and the evidence of substantial decline of waterbird species like Spur-winged Plover in particular demonstrate the urgent need to implement appropriate conservation action plans in the Küçük Menderes Delta.

Acknowledgements: We would like to thank the Scientific and Technological Research Council of Turkey (TUBITAK) for supporting our work within the 2209 Support Programme. In addition, we express our gratitude to Dr Peter Sackl (Universalmuseum Joanneum, Graz, Austria) for his valuable assistance and comments.

\section{Povzetek}

Med 3. in 18.5.2008 so avtorji raziskovali status in razširjenost gnezdečih ptic v delti Küçük Menderes ob obali Egejskega morja v zahodni Turčiji. $49 \mathrm{~km}^{2}$ veliko raziskovano območje je bilo razdeljeno na 49 kilometrskih UTM-kvadratov. V vsakem kvadratu so bila opravljena 2-3 štetja po točkovni metodi, skupaj 139 štetij. Od 54 vrst z gnezditvenim statusom so avtorji 19 vrst (35\%) opredelili kot možne gnezdilke, $23(43 \%)$ kot verjetne gnezdilke in 12 (22\%) kot potrjene gnezdilke. Trenutna razširjenost vseh gnezdilk je prikazana na kartah. Čopasti škrjanec Galerida cristata, svilnica Cettia cetti, domači vrabec Passer domesticus in bledi vrtnik Hippolais pallida so bili zabeleženi v več kot $50 \%$ vseh kvadratov, več kot 10 gnezdečih vrst pa v kvadratih z različnimi vodnimi in sezonsko poplavljenimi habitati vzdolž obale Egejskega morja, a tudi v okolici brakičnih in sladkovodnih jezer. $\mathrm{V}$ mnogih kvadratih z velikim deležem kmetijskih zemljišč in slanimi poloji je bilo zabeleženih manj kot 10 gnezdečih vrst. Majhno število gnezdečih vodnih ptic v delti avtorji pripisujejo požiganju trstišč med gnezditveno sezono in vznemirjanju s strani človeka, kot so npr. rekreacijske dejavnosti in nezakonito streljanje ptic.

\section{References}

Akarsu, F. \& Balkiz, Ö. (20I0): [Mid-winter Waterfowl counts in Turkey 2008-2009-2010.] - Doğa Derneği, Ankara, Turkey. (in Turkish)

Bibby, C., Jones, M. \& Marsden, S. (I998): Expedition Field Techniques: Bird Surveys. - Royal Geographical Society, London.

BirdLife International (200I): Important Bird Areas and potential Ramsar Sites in Europe. - BirdLife International, Wageningen.

BirdLIFE INTERNATIONAL (2004): Birds in Europe: population estimates, trends and conservation status. BirdLife Conservation Series No. 12. - BirdLife International, Cambridge.

BirdLife International (20II): Important Bird Areas factsheet: Küçük Menderes delta. - [http://www.birdlife. org/datazone/sitefactsheet.php?id=761], 7/4/2011.

Bolca, M., Altindas, U., Kurucu, Y. \& Esetlili, T. (2005): Determination of Change Detection of Landscape of the Küçük Menderes Delta Using GIS and Remote Sensing Techniques. - Journal of Applied Sciences 5 (4): 659-665.

Donald, P.F. \& Fuller, R.J. (1998): Ornithological atlas data: a review of uses and limitations. - Bird Study 45: 129-145.

EAgLes, P.F.J. (1990): Uses of Atlas Data. In: Smith, C.R. (ed.): Handbook for Atlasing North American Breeding Birds. - Vermont Institute of Natural Science, Quechee. [http://www.bsc-eoc.org/norac/atlascont.htm]

Eken, G., Bozdogan, M., Isfendiyaroglu, S., Kiliç, D.T. \& Lise, Y. (eds.) (2006) : [Key Biodiversity Areas of Turkey.] - Doğa Derneği, Ankara. (in Turkish)

Gregory, R.D., Bashford, R.I., Balmer, D.E., Marchant, J.H., Wilson, A.M. \& Baillie, S.R. (1996): The Breeding Bird Survey, 1995-1996. - British Trust for Ornithology, Thetford.

Hagemeijer, W.J.M. \& Blair, M.J. (1997): The EBCC Atlas of European Breeding Birds: Their Distribution and Abundance. - T \& A D Poyser, London.

Heath, M.F. \& Evans, M.I. (eds.) (2000): Important Bird Areas in Europe: Priority sites for conservation. BirdLife Conservation Series No. 8. - BirdLife International, Cambridge.

Karadeniz, N., Tiril, A. \& Baylan, E. (2009): Wetland management in Turkey: Problems, achievements and perspectives. - African Journal of Agricultural Research 4 (11): 1106-1119.

Kiliç, D.T. \& Eken, G. (2004): [Important Bird Areas of Turkey - 2004 Update.] - Doğa Derneği, Ankara. (in Turkish)

Kirwan, G., Boyla, K., Castell, P., Demirci, B., Özen, M., Welch H. \& Marlow, T. (2008): The Birds of Turkey. - Christopher Helm, London.

KusBank (20IO): Region Checklist Query. - [www.kusbank. org], 23/08/2010. 
Mitsch, W.J. \& Gosselink, J.G. (2007): Wetlands. $4^{\text {th }}$ Edition. - John Wiley \& Sons, New York.

Onmuş, O. (2007): [Mid-winter Waterfowl counts in Turkey 2007.] - Doğa Derneği, Ankara. (in Turkish)

Onmuş, O., Durusoy, R. \& Eken, G. (2009): Distribution of breeding birds in the Gediz Delta, Western Turkey. Zoology in the Middle East 47: 39-48.

Per, E., Yaşar, A., Özesmi, L. \& ÖZesmi, U. (2002): Turkish Breeding Bird Atlas Pilot Project 2001: Erciyes Mountain and Kayseri Region. - Bird Census News 15 (1): 2-21.

SIKI, M. (1997): [Overview on Selçuk (İzmir) Bird Paradise - From Past to Present.] pp. 165-168 In: $1^{\text {st }}$ International Selçuk Symposium, 4-6 September 1997, Selçuk, Turkey. - The Municipality of Selçuk. (in Turkish)

Somay, M., Gemici, Ü. \& Filiz S. (2008): Hydrogeochemical investigation of Kucuk Menderes River coastal wetland, Selcuk - Izmir, Turkey. - Environmental Geology 55: 149-164.

Suseven, B., Onmuş, O. \& İsfendiyaroĞlu, S. (2006): [Mid-winter Waterfowl counts in Turkey 2006.] - Doğa Derneği, Ankara. (in Turkish)

Arrived / Prispelo: 14.8.2009

Accepted / Sprejeto: 22.6.2011

\section{APPENDIX 1 / DODATEK 1}

Distribution of breeding birds in the Küçük Menderes Delta (western Turkey) according to the atlas mapping carried out in May 2008. Breeding status is indicated with different colours: light grey, dark grey and black representing possible, probable and confirmed breeding, respectively (pages 122-130).

Razširjenost gnezdilk v delti Küçük Menderes (zahodna Turčija) na osnovi kartiranja maja leta 2008. Gnezditveni status ptic je označen z različnimi barvami: svetlo siva barva označuje možno, temno siva verjetno in črna barva potrjeno gnezdenje (strani 122-130). 
Dodatek 1 / Appendix 1: naslov glej str. 121 / title see page 121

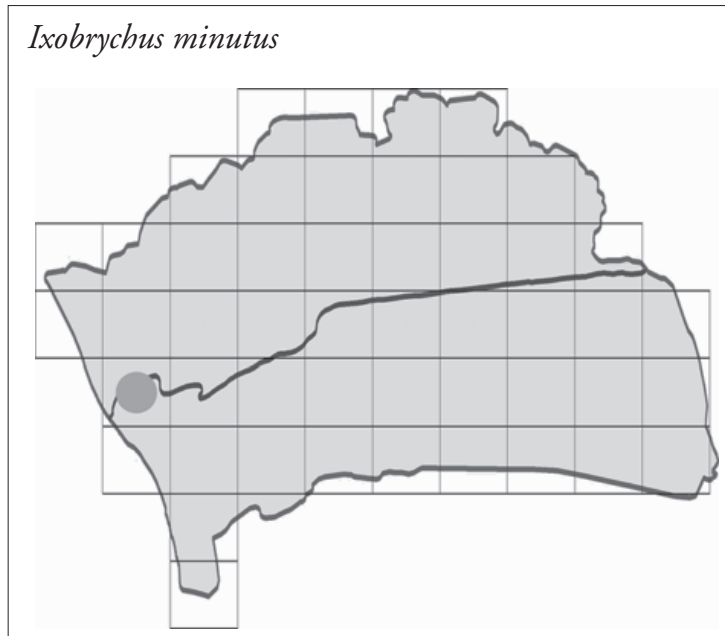

Tadorna ferruginea

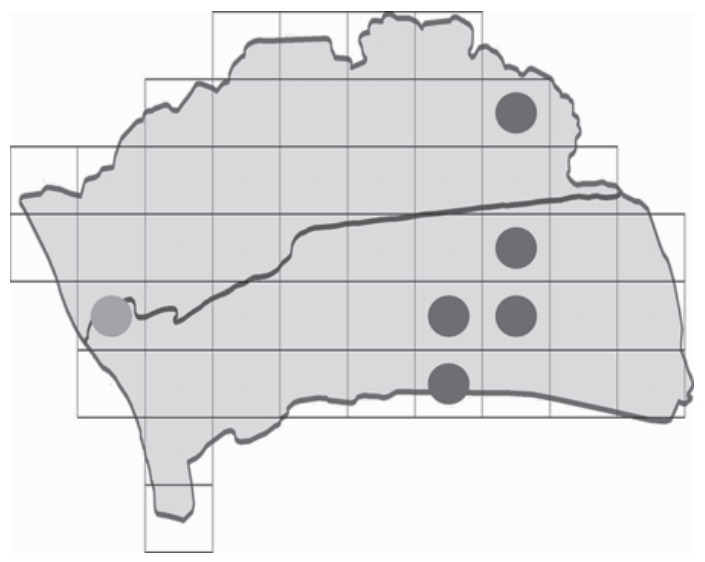

Buteo buteo

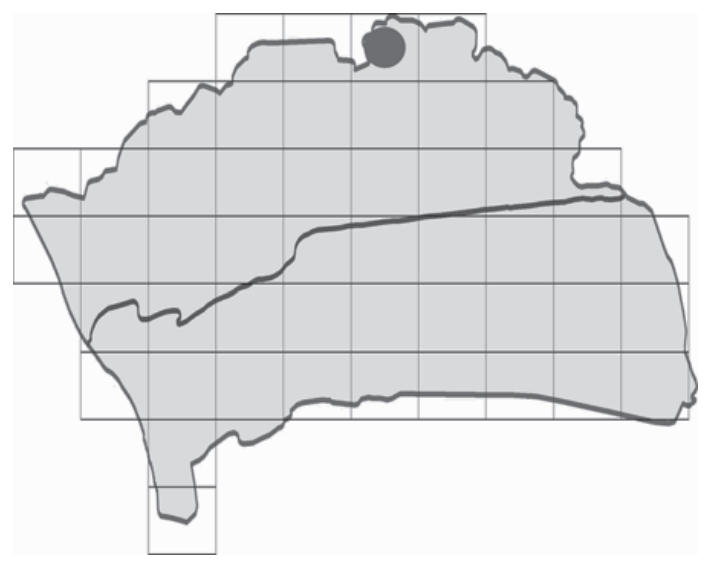

Ciconia ciconia

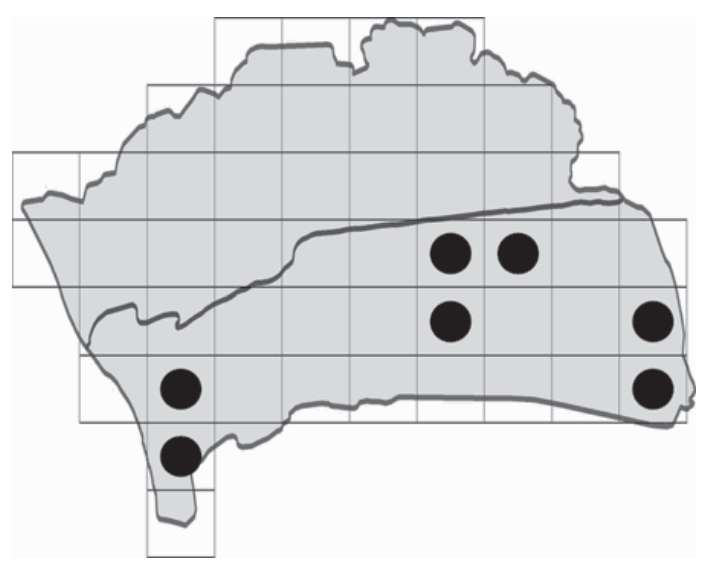

Anas platyrhynchos

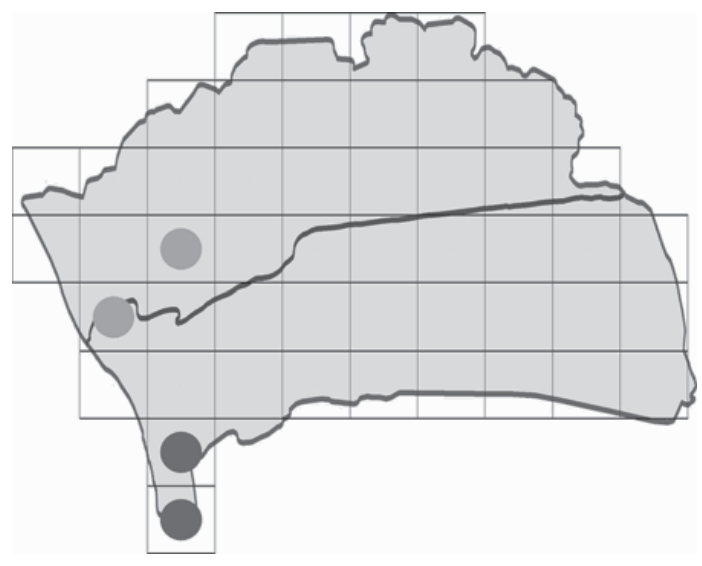

Falco tinnunculus

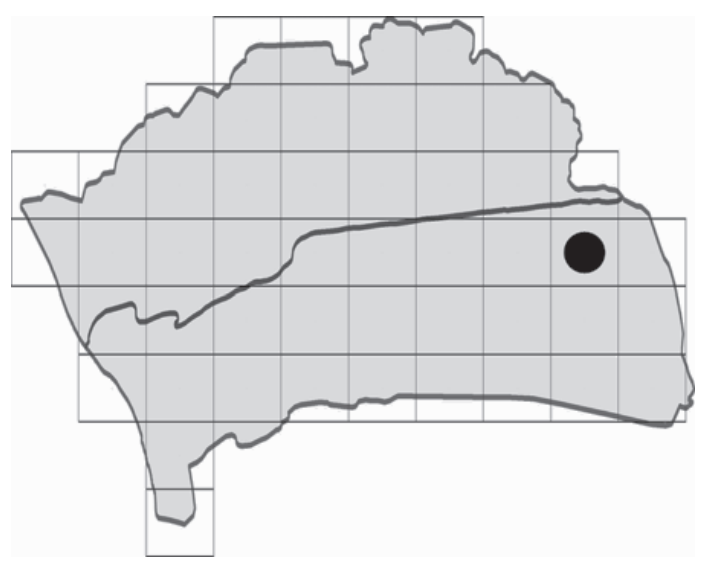


Nadaljevanje dodatka 1 / continuation of Appendix 1

\section{Gallinula chloropus}

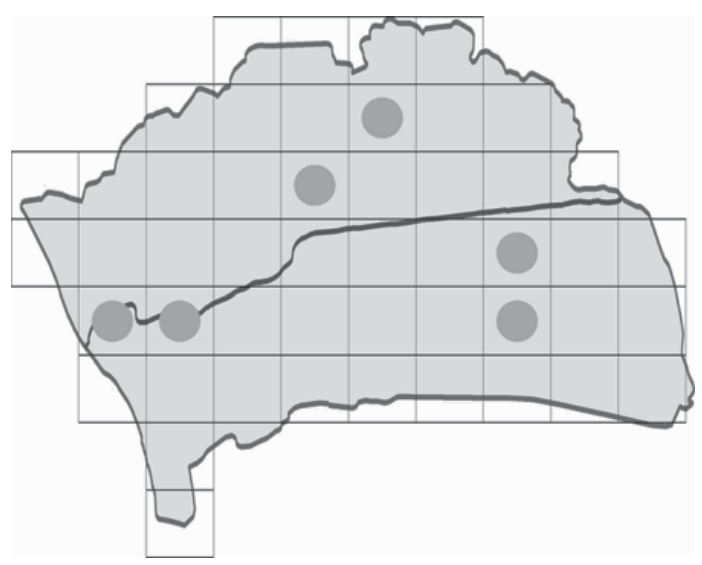

Himantopus himantopus

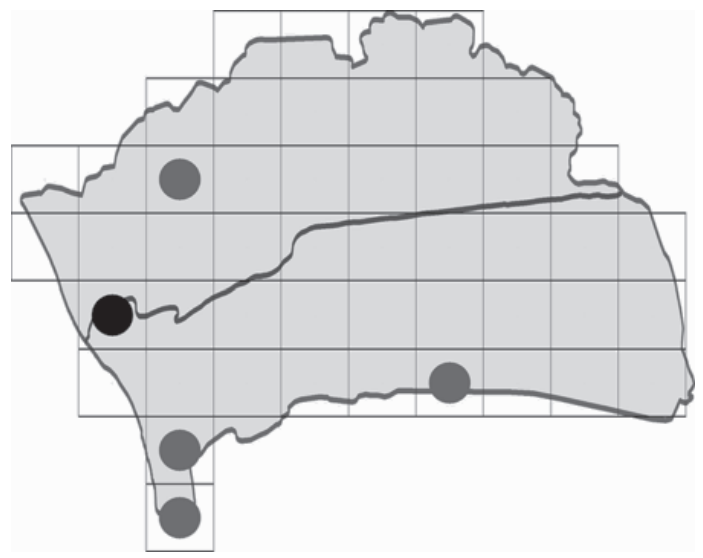

Charadrius dubius

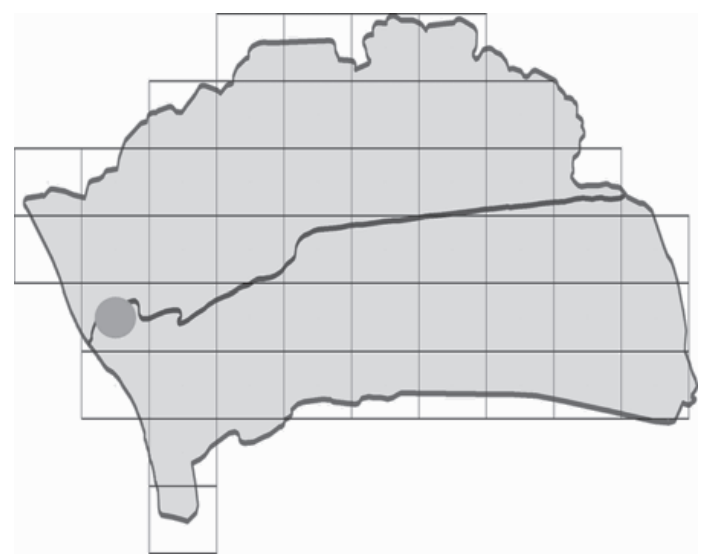

\section{Fulica atra}

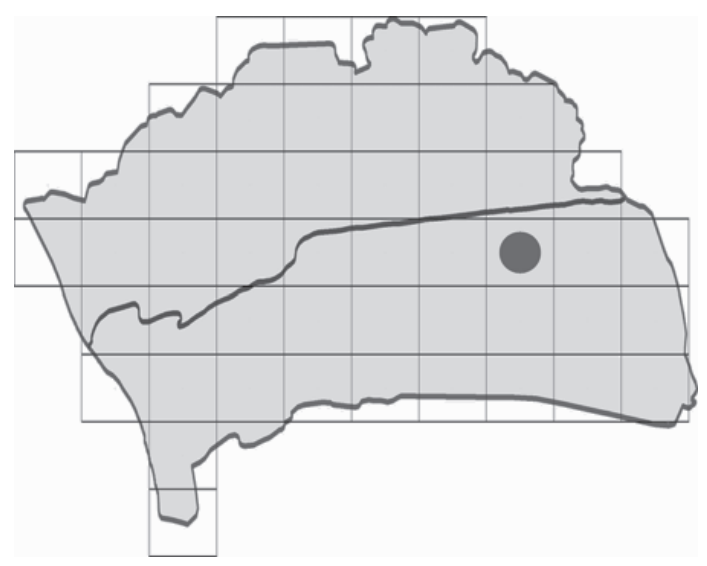

Glareola pratincola

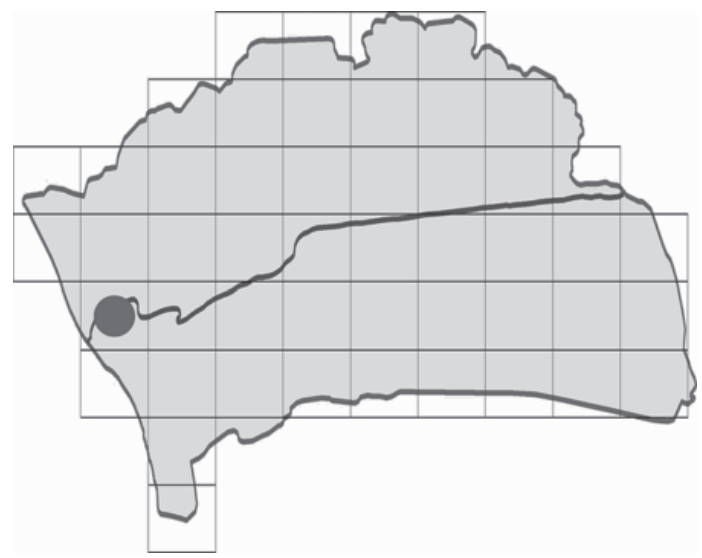

Charadrius alexandrinus

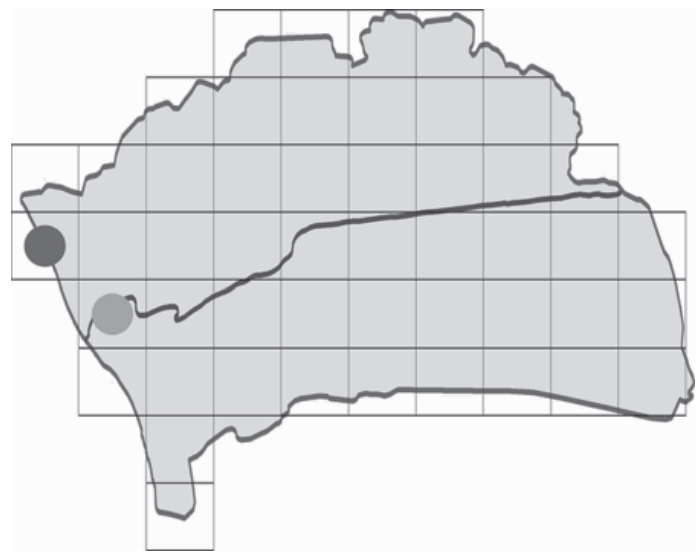


Nadaljevanje dodatka 1 / continuation of Appendix 1
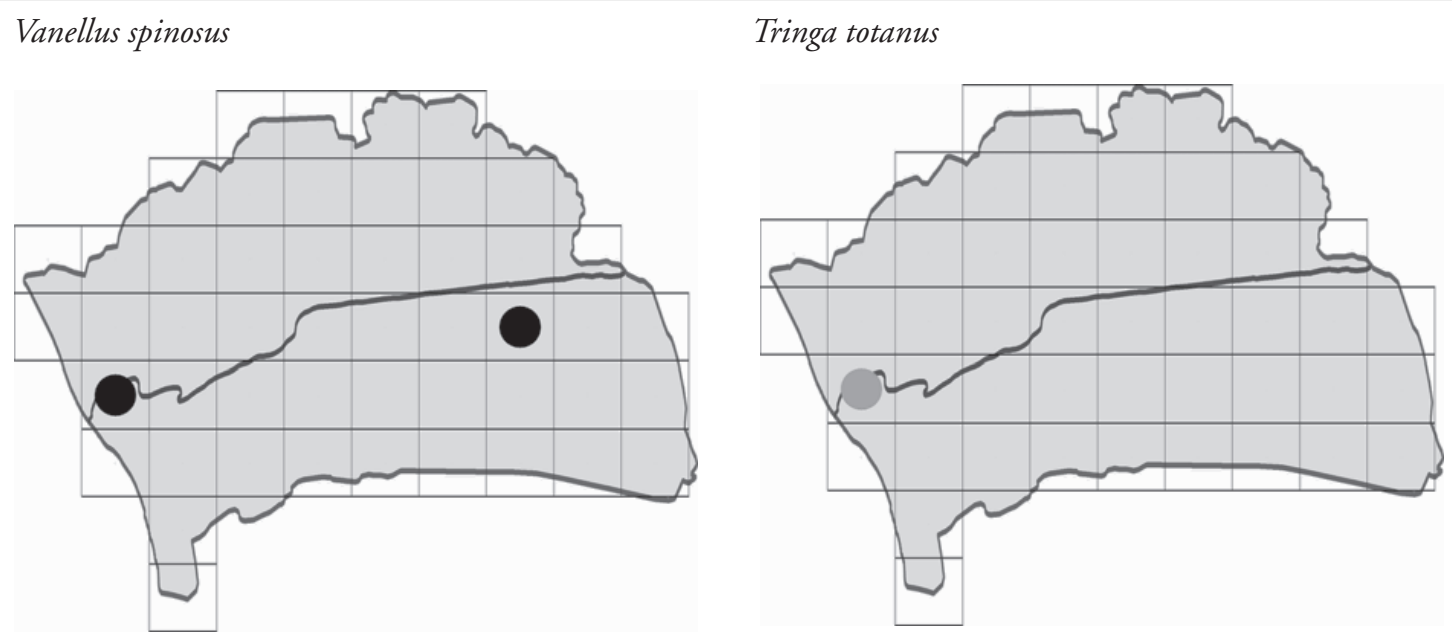

Actitis hypoleucos

\section{Chlidonias niger}
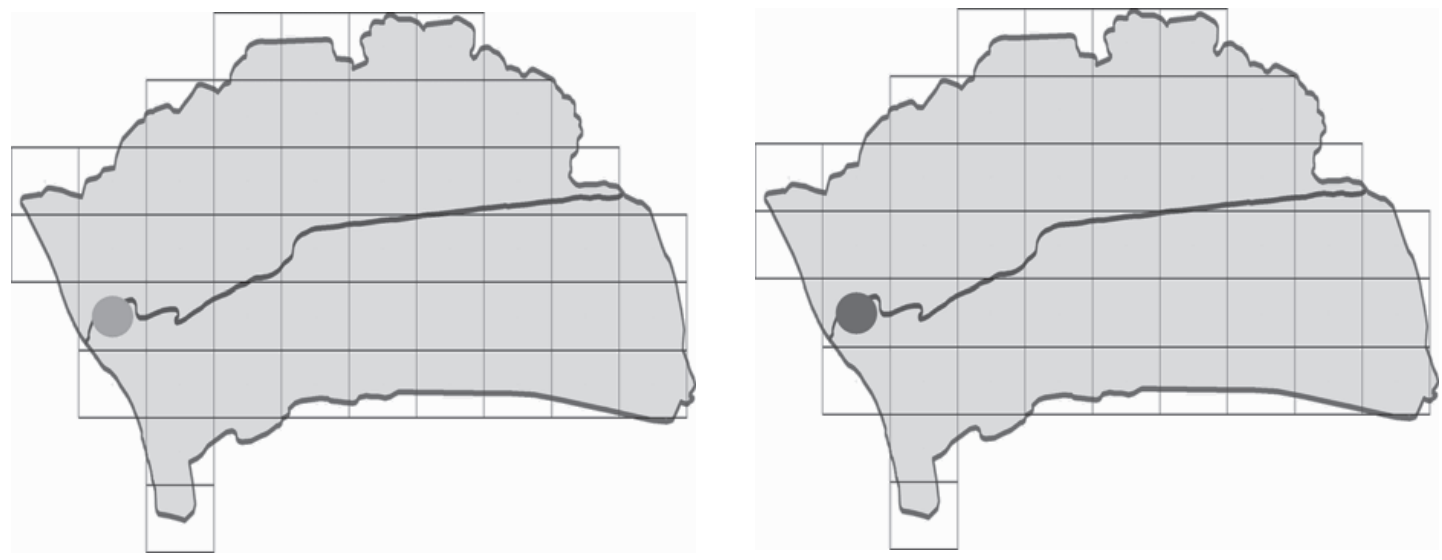

Chlidonias leucopterus

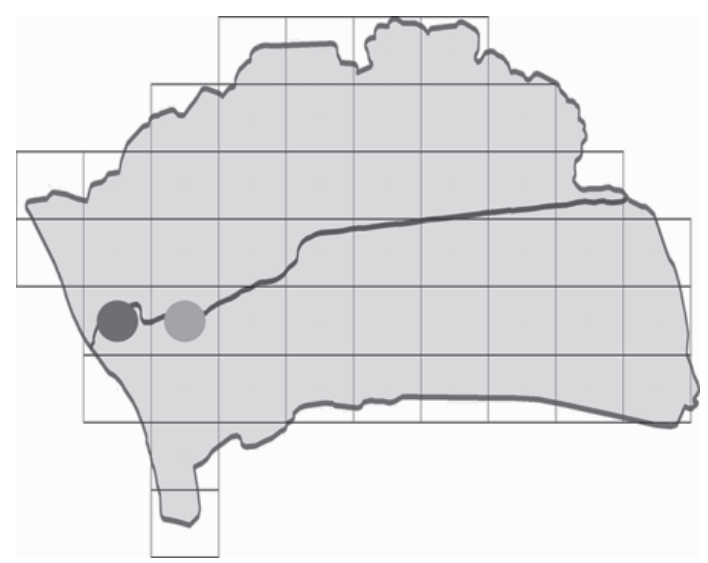

Streptopelia decaocto

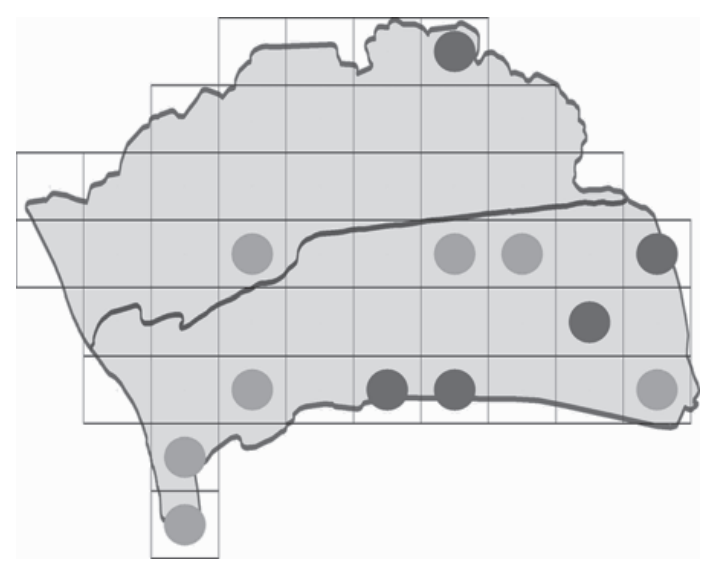


Nadaljevanje dodatka 1 / continuation of Appendix 1

\section{Streptopelia turtur}

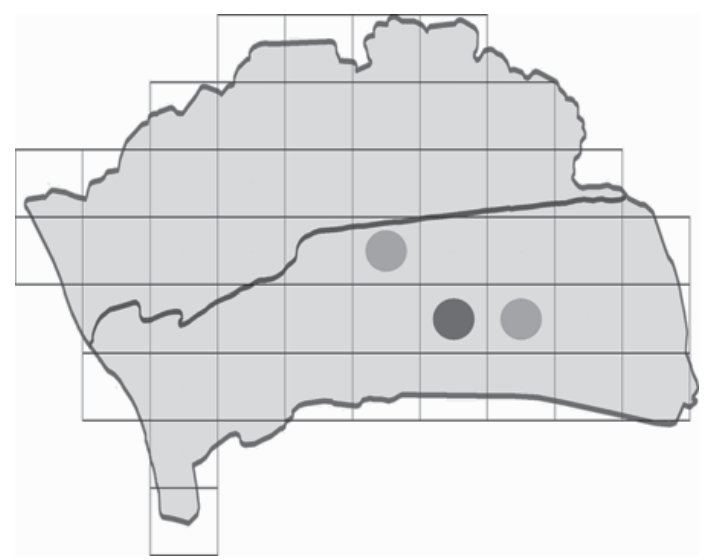

Cuculus canorus

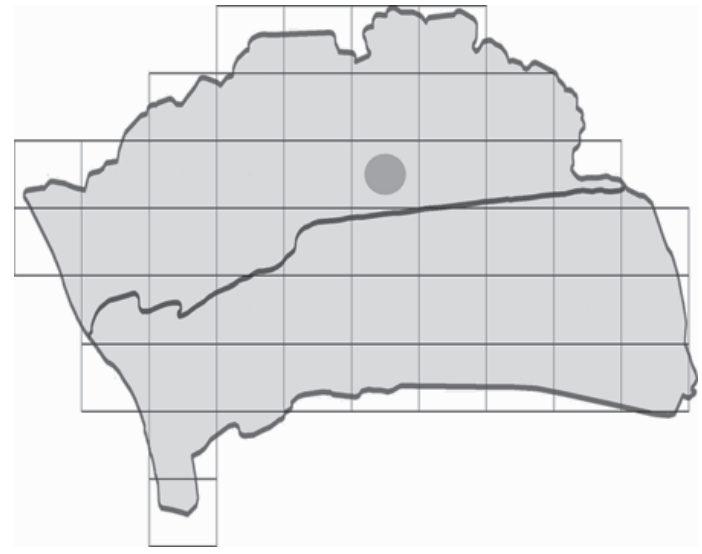

Coracias garrulus

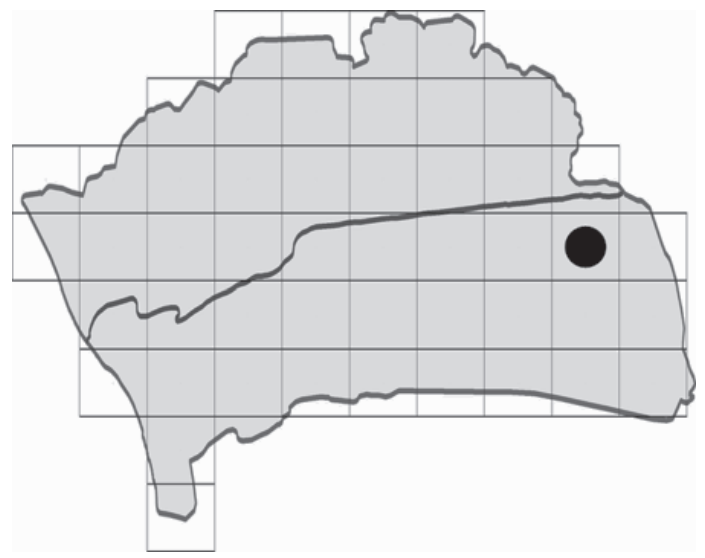

Clamator glandarius

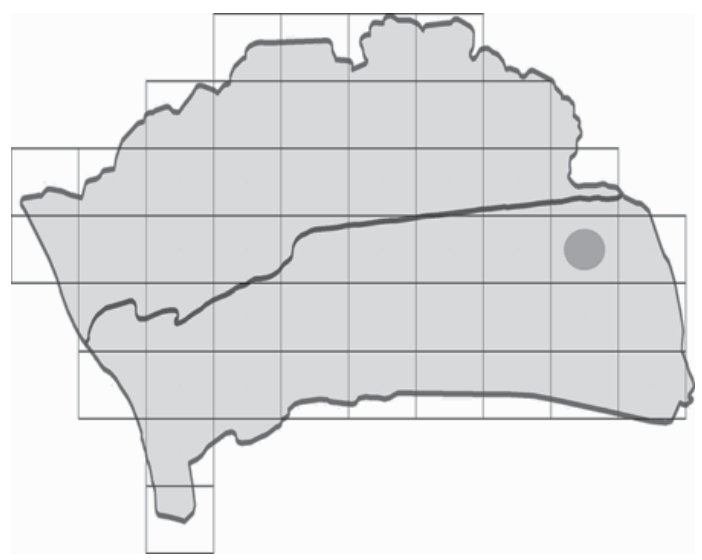

Athene noctua

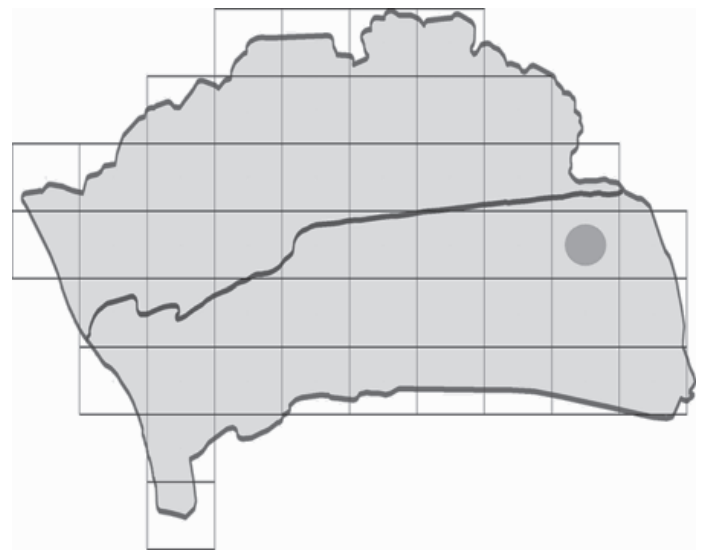

Upupa epops

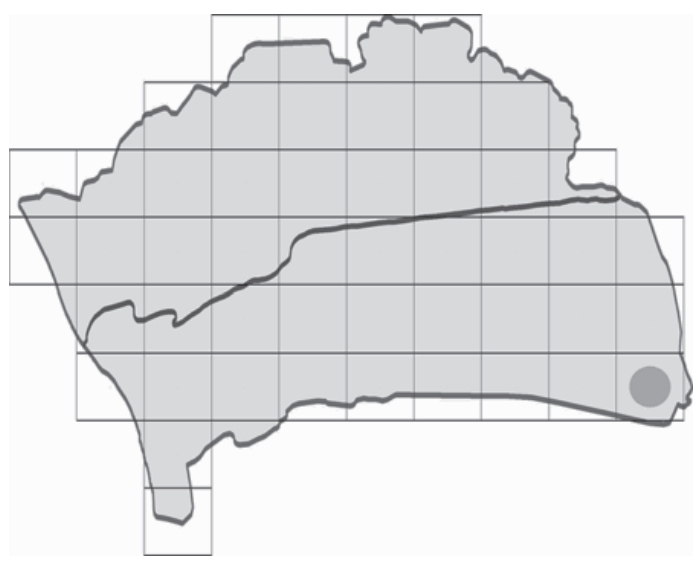


Nadaljevanje dodatka 1 / continuation of Appendix 1

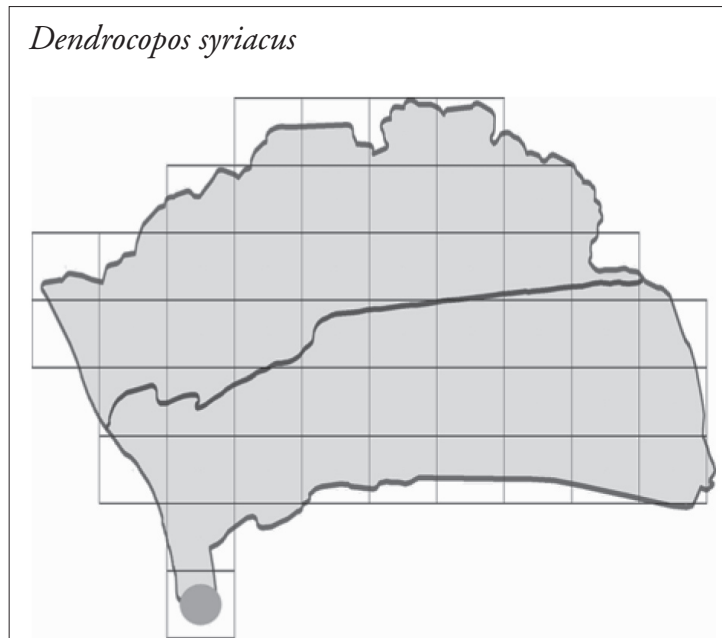

Galerida cristata

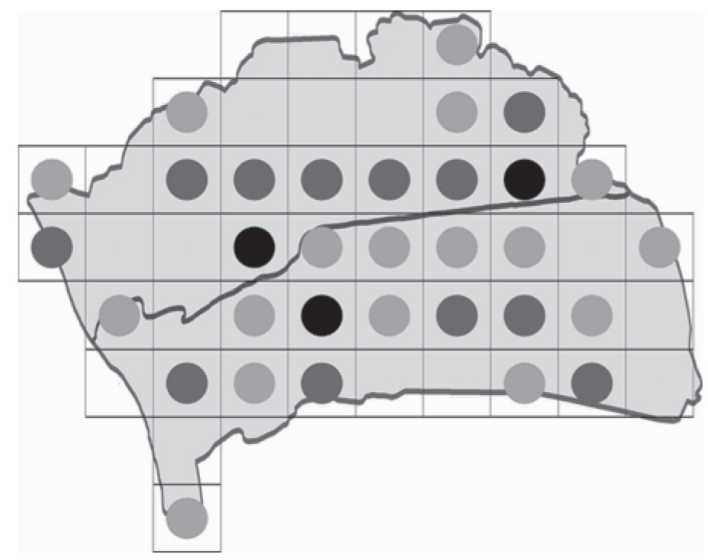

\section{Delichon urbicum}

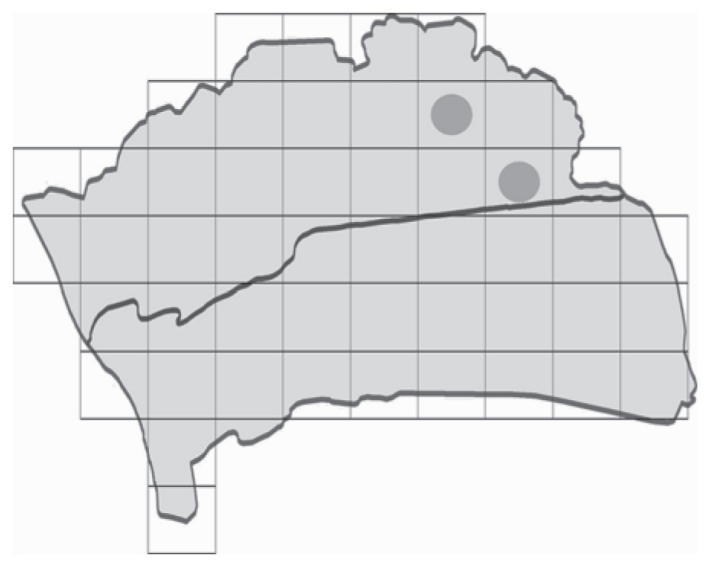

\section{Melanocorypha calandra}

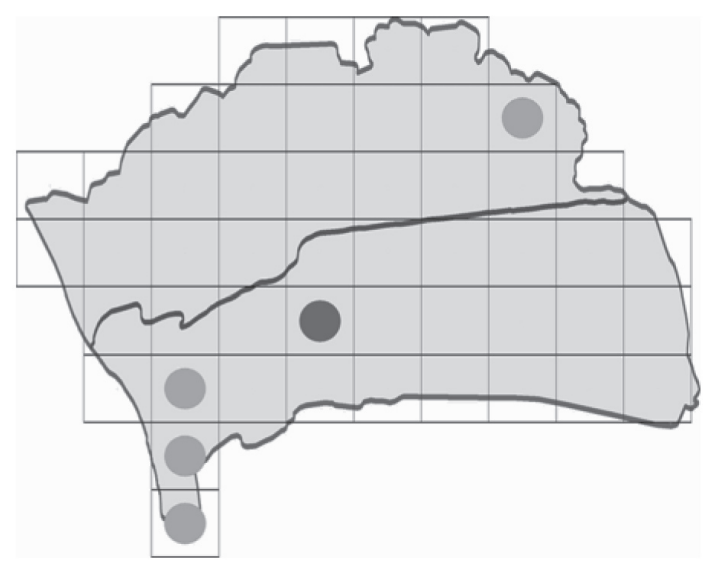

Hirundo rustica

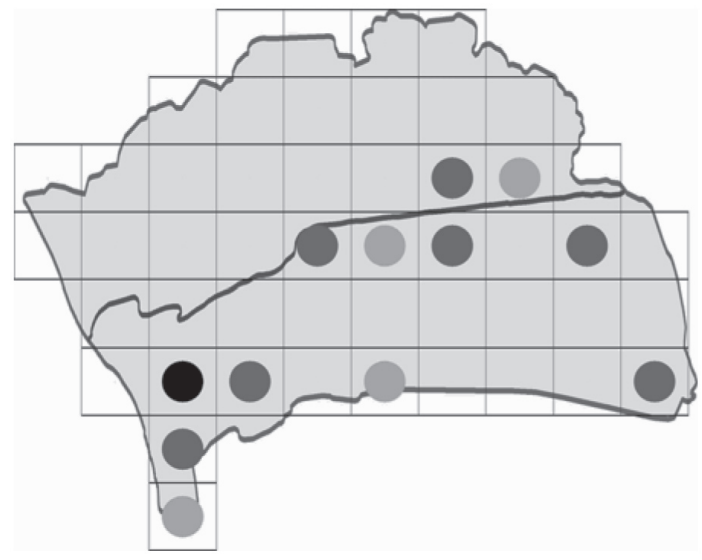

Motacilla flava

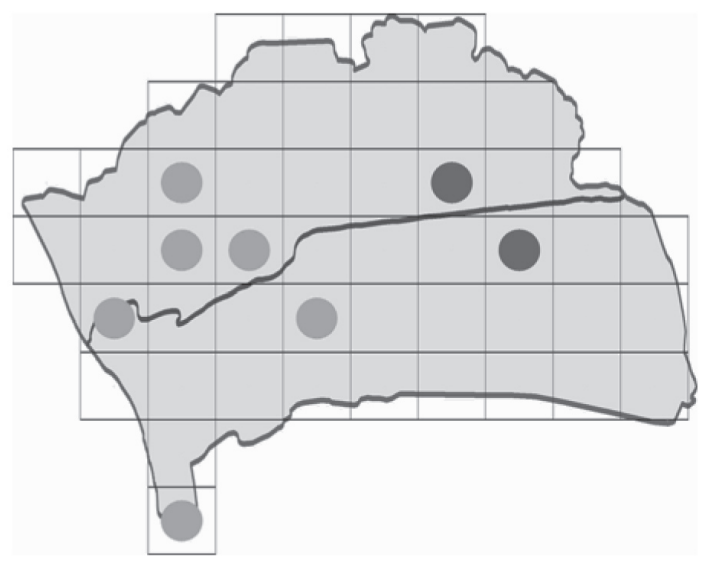


Nadaljevanje dodatka 1 / continuation of Appendix 1

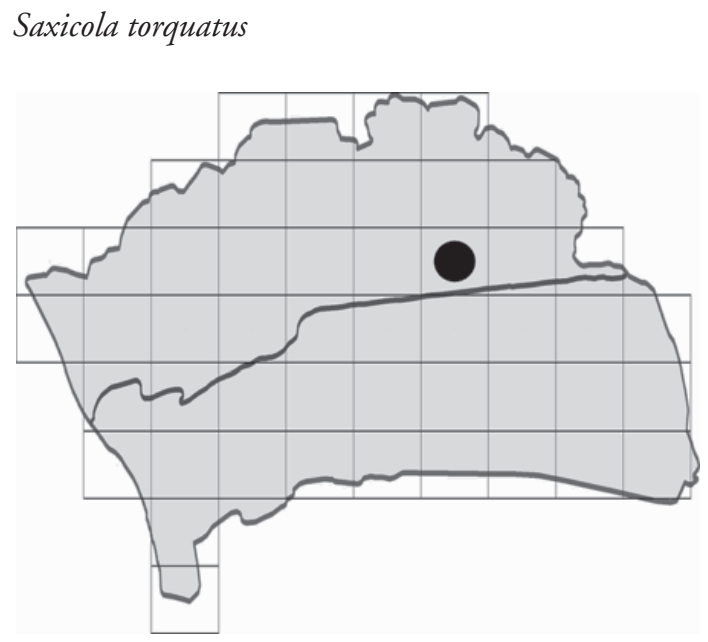

Cettia cetti

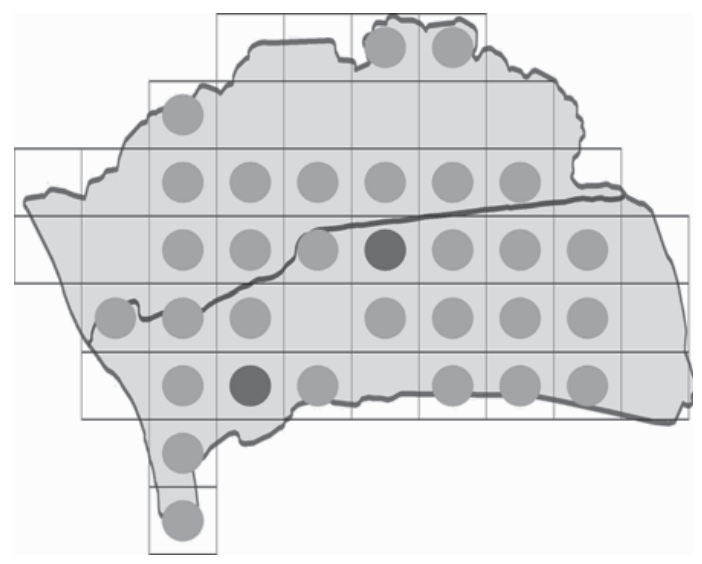

Acrocephalus scirpaceus

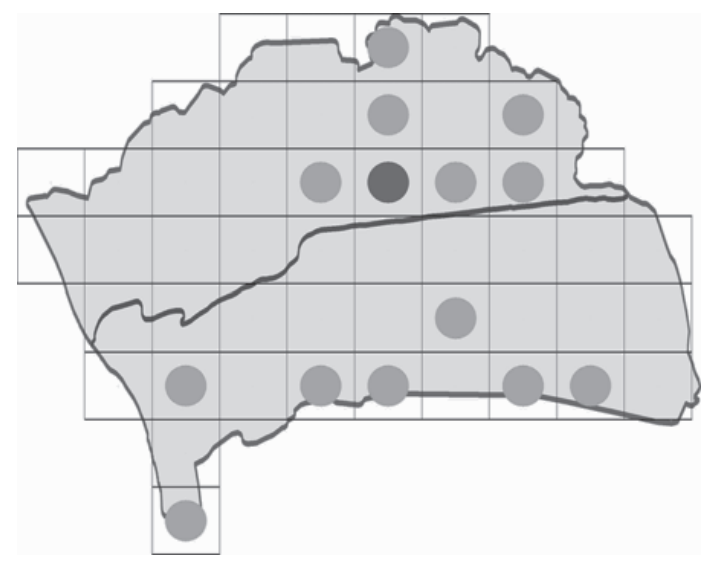

Turdus merula

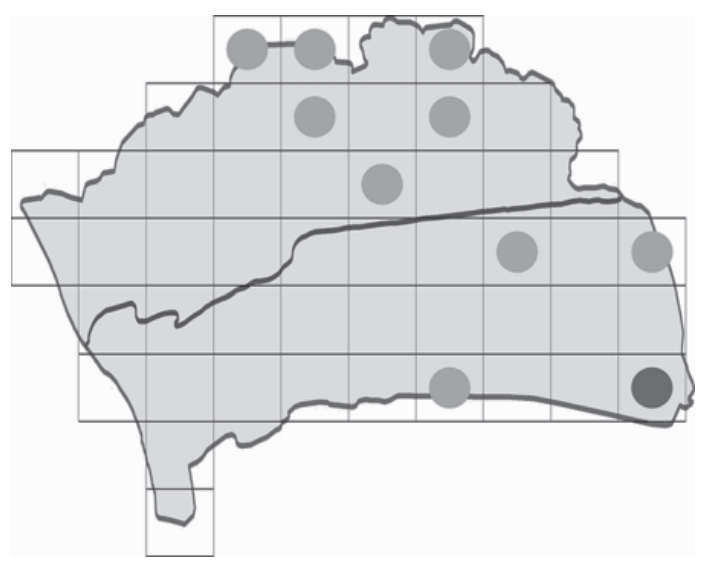

Cisticola juncidis

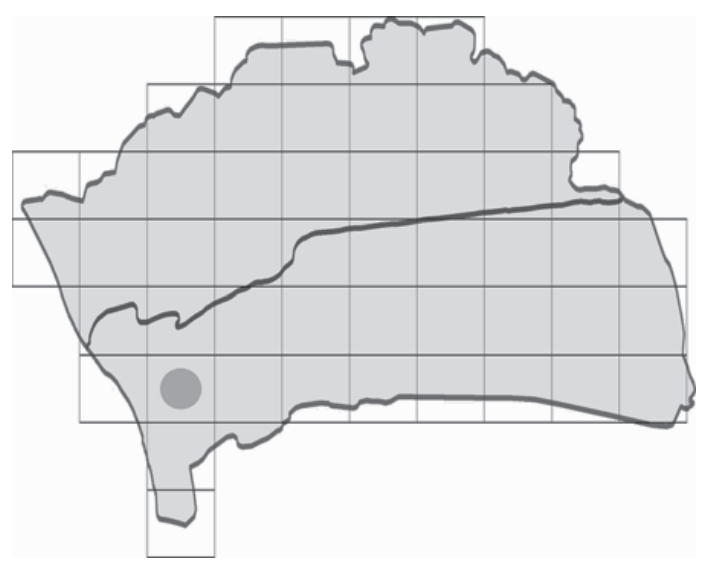

Acrocephalus arundinaceus

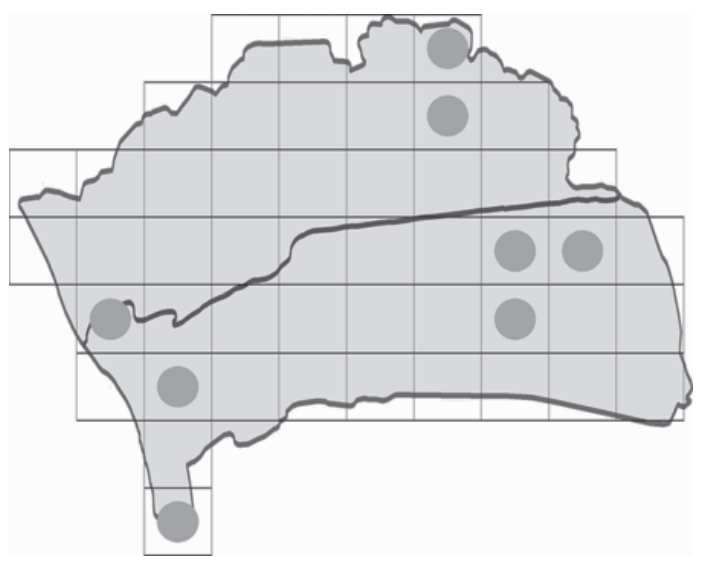


Nadaljevanje dodatka 1 / continuation of Appendix 1

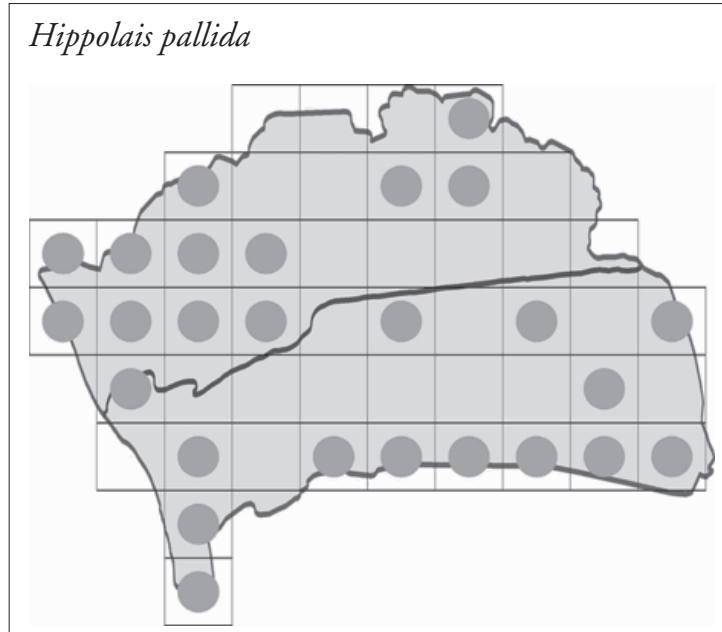

Parus major

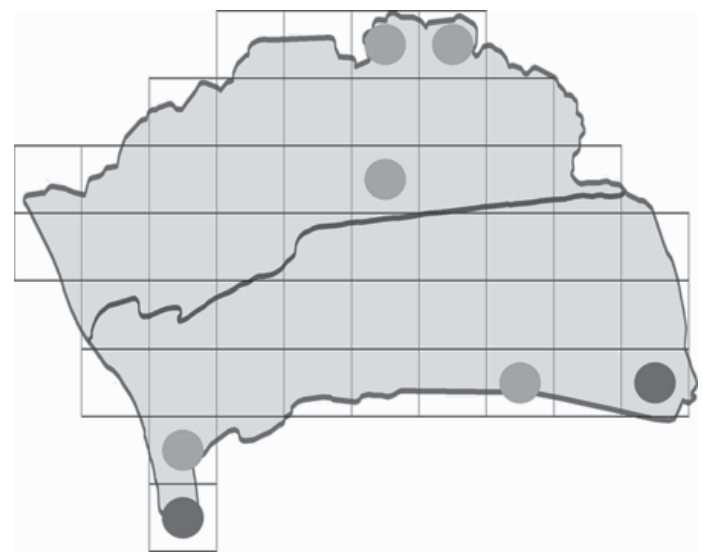

Lanius collurio

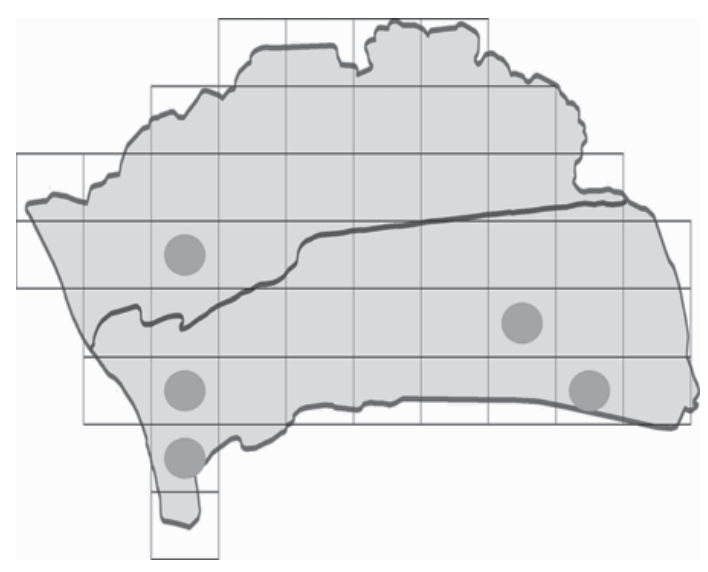

\section{Muscicapa striata}

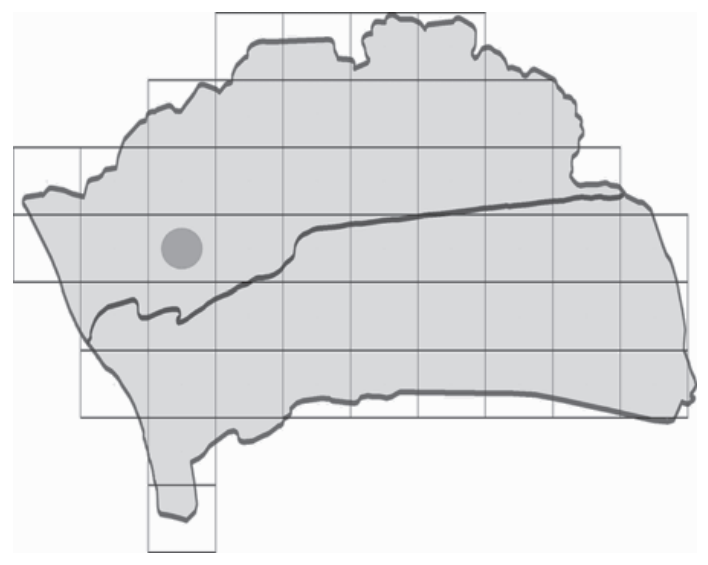

Remiz pendulinus

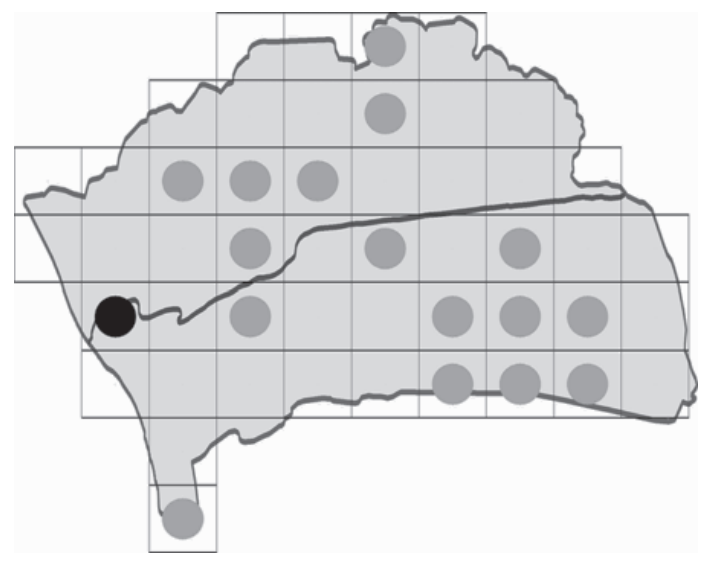

Lanius minor

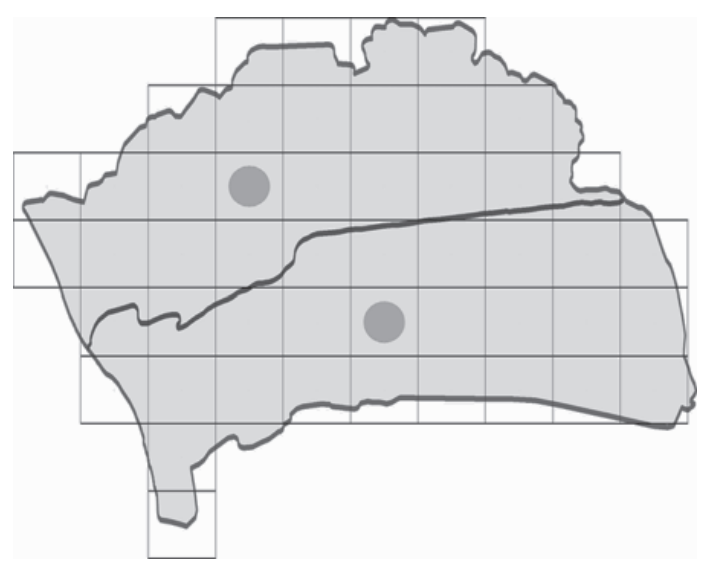


Nadaljevanje dodatka 1 / continuation of Appendix 1

\section{Lanius senator}

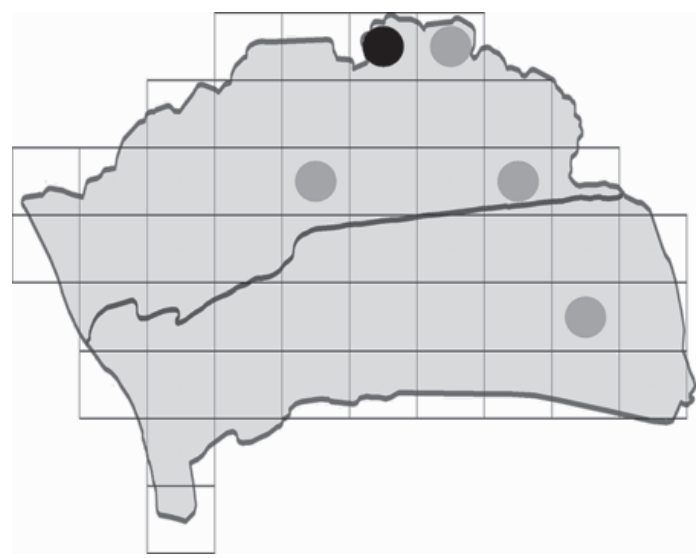

Pica pica

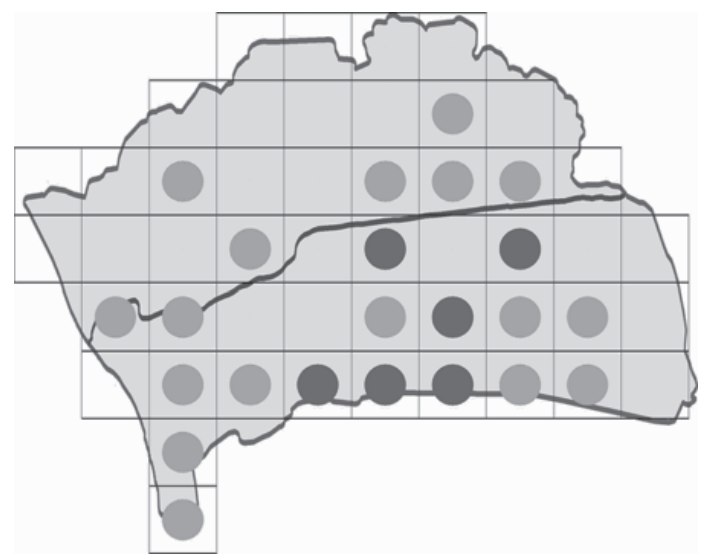

Corvus cornix

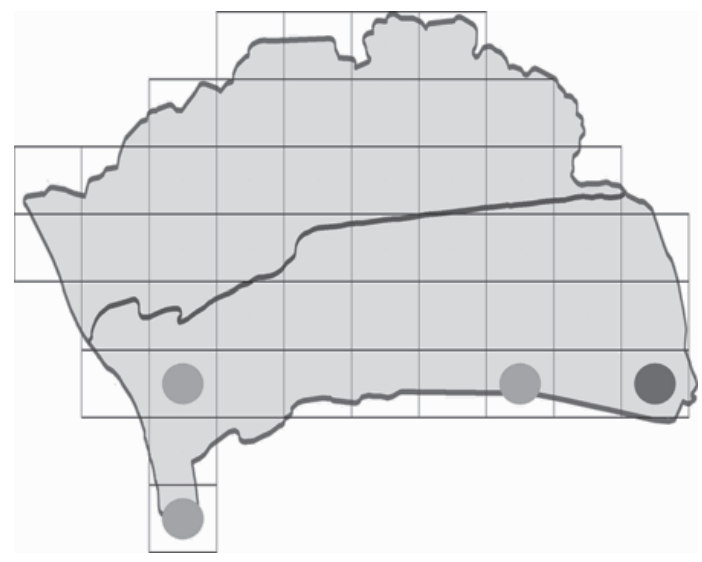

Garrulus glandarius

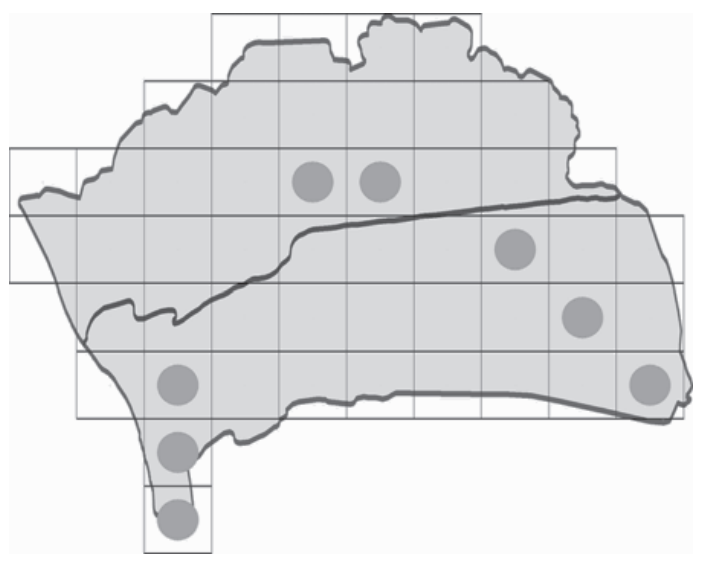

Corvus monedula

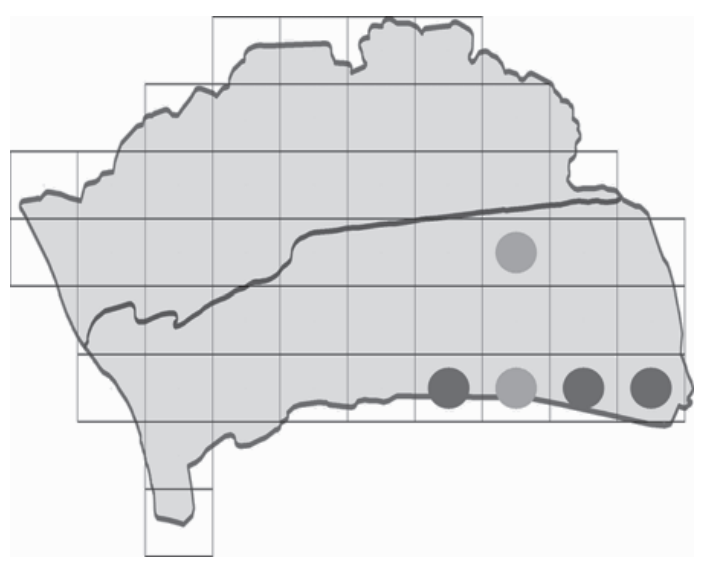

Passer domesticus

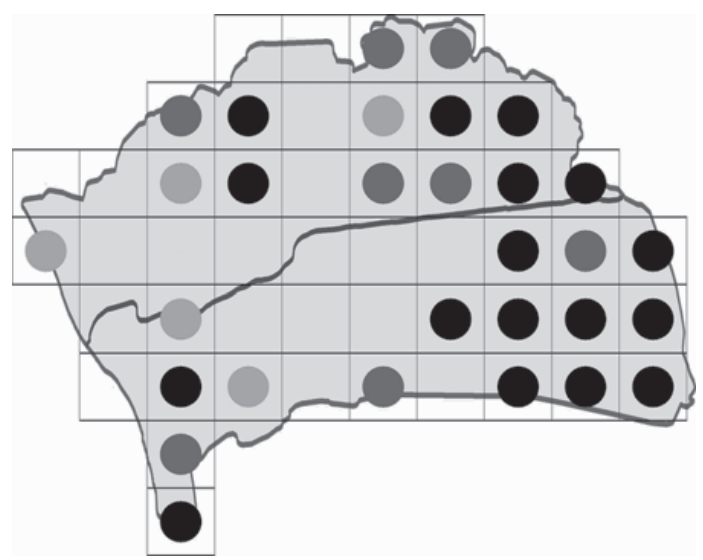


Nadaljevanje dodatka 1 / continuation of Appendix 1

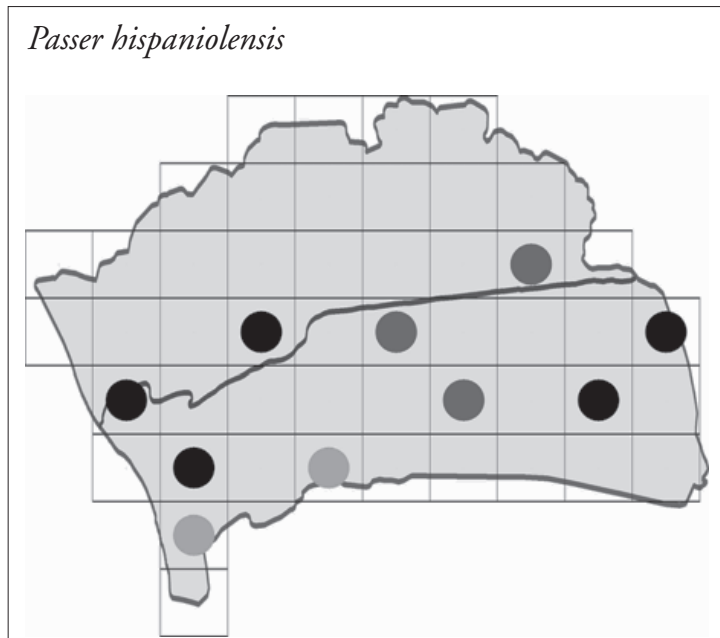

Carduelis carduelis

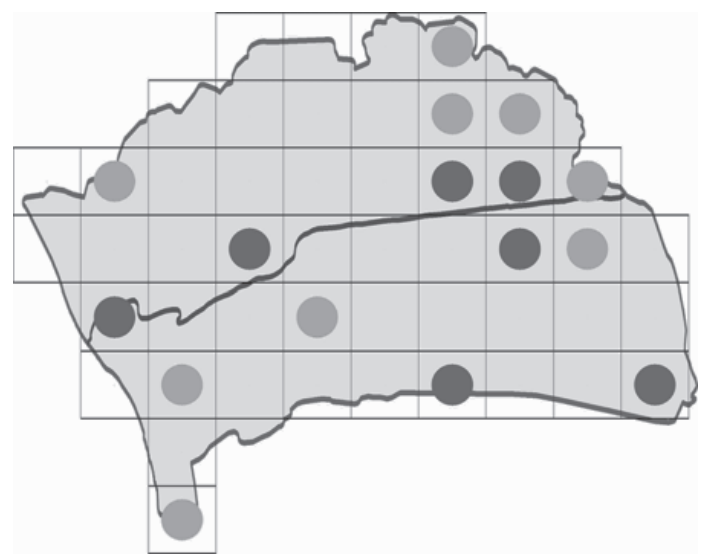

Emberiza melanocephala

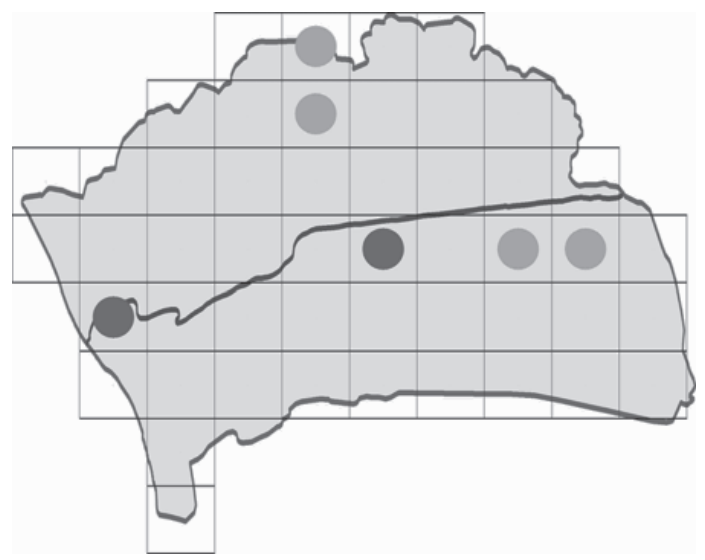

Carduelis chloris

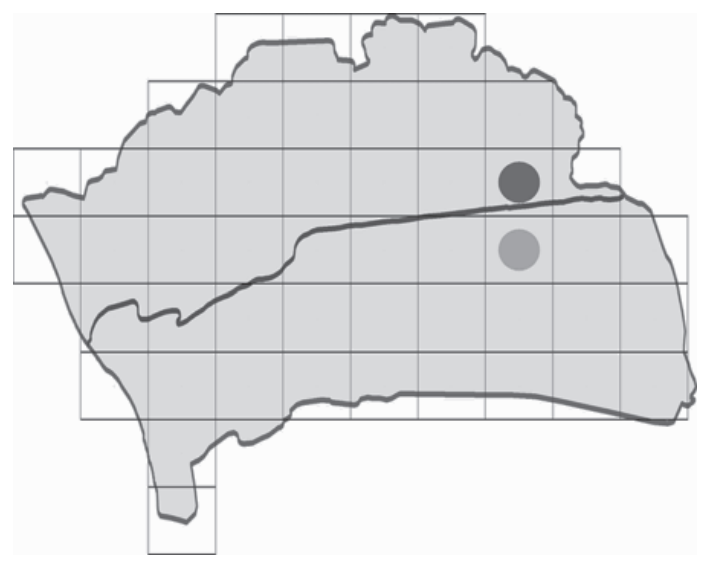

Emberiza cirlus

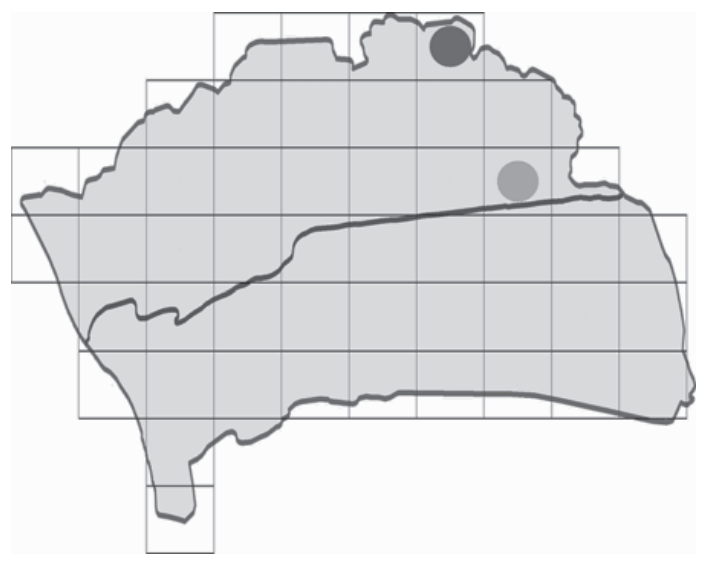

Miliaria calandra

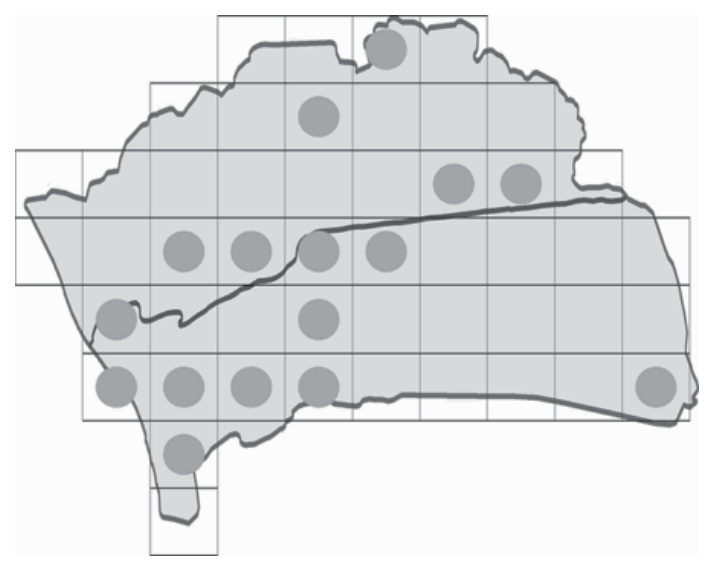

